\title{
Analysis of the Mechanism of Action of Biological Therapies in Monotherapy in Patients with Rheumatoid Arthritis: Beyond the ADACTA Study
}

\author{
M Victoria Hernández ${ }^{1 *}$, Silvia Vidal ${ }^{2}$ and Raimon Sanmarti ${ }^{1}$ \\ ${ }^{1}$ Arthritis Unit, Rheumatology Department, Hospital Clinic, University of Barcelona, Spain \\ ${ }^{2}$ Immunology Department, Hospital Sant Pau, University Autonoma, Barcelona, Spain
}

\begin{abstract}
The recently-published first head-to-head study comparing the efficacy of two biological drugs on monotherapy, tocilizumab and adalimumab, found better results for tocilizumab. Both are cytokine-specific antagonists: adalimumab targets tumor necrosis factor and tocilizumab targets interleukin- 6 receptor.

The aim of our review was to determine differences in the mechanisms of action of adalimumab and tocilizumab, in order to explain the differing results found, and to describe the immunologic and clinical aspects of the two drugs.
\end{abstract}

Keywords: ADACTA study; Tocilizumab; Adalimumab; Tumor necrosis factor; Interleukin-6; Mechanism of action; Immune system

\section{Introduction}

In the last decade, biological therapies have dramatically improved the prognosis of patients with Rheumatoid Arthritis (RA). The first biological agents used were Tumor Necrosis Factor (TNF) antagonists, which specifically block this proinflammatory cytokine. Currently, there are five biological drugs that target TNF: infliximab, etanercept, adalimumab, and the more-recently approved certolizumab and golimumab. All have been approved as therapy for RA patient's refractory to disease-modifying antirheumatic drugs (DMARDs) [15]. In addition, other agents have been approved for the treatment of RA patients, including rituximab, a selective CD-20-positive B-cell depletion therapy; abatacept, a selective T-cell co-stimulation modulator; and tocilizumab, a humanized anti-interleukin-6 (IL-6) receptor antibody. All have proven efficacy in RA patients compared with methotrexate [6-8], and in TNF antagonist-refractory patients [9-11]. However, until now, there have been no head-to-head studies comparing the efficacy of two biological drugs in RA patients. Only the AMPLE study [12], that was undertaken to compare subcutaneous (SC) abatacept and SC adalimumab, could be considered a head-tohead study, but in this case, both biological agents were administered along with background methotrexate and no differences in efficacy were found between them.

The recent published ADACTA study compares the efficacy of adalimumab and tocilizumab in monotherapy at 24 weeks [13]. The results were favorable to tocilizumab over adalimumab.

One question the results pose is why tocilizumab was superior to adalimumab, a well-established and efficacious TNF antagonist. In other words, what are the differences in the mechanism of action of these two cytokine-specific biologic agents that might explain these results?

The aim of our review was to determine differences in the mechanisms of action of adalimumab and tocilizumab, in order to explain the results of the ADACTA head-to-head study [13], and to describe the immunologic and clinical aspects of the two drugs.

\section{The ADACTA study}

ADACTA is the first head-to-head study comparing two biological agents, tocilizumab and adalimumab on monotherapy. ADACTA was a phase 4 superiority study to compare the efficacy of the two drugs in monotherapy at 24 weeks. The characteristics of the study are described elsewhere [13]. Briefly, patients with severe RA intolerant to methotrexate or who were inappropriate for continued methotrexate treatment were included. The primary outcome was the difference in the DAS-28 score at 24 weeks compared with baseline. Secondary outcomes included the percentage of patients achieving ACR20, ACR50 and ACR70 responses; the proportion of patients achieving remission (defined as DAS-28 $\leq$ 2.6) or low activity (DAS- $28 \leq 3.2$ ), and good and moderate EULAR response, all at week 24 . Other measurements, including disability (HAQ questionnaire), fatigue (FACIT questionnaire), and quality of life (SF-36 health survey) were analyzed at week 24 . In a post-hoc analysis, the proportion of patients achieving remission or low activity according to the CDAI score was also analyzed.

At 24 weeks, tocilizumab showed a significantly-greater mean change in DAS28 from baseline (-3.3) compared with adalimumab $(-1.8)$ [diference-1.5, (95\%, CI-1.8 to -1.1$), \mathrm{p}<0.0001$ ] [13]. The tocilizumab group had a significantly-higher number of patients achieving ACR 20, ACR 50 and ACR 70 responses compared with adalimumab. A significantly-higher proportion of patients treated with tocilizumab compared to adalimumab achieved DAS-28 remission (39.9\% vs $10.5 \%, \mathrm{p}<0.0001)$, DAS- 28 low disease activity $(51.5 \%$ vs $19.8 \%, \mathrm{p}<0.0001)$ and EULAR good or moderate responses $(77.9 \%$ vs $54.9 \%, \mathrm{p}<0.0001$ ) [13]. Comparison using the CDAI (a disease index that not include acute phase reactants) also showed significantly- better results for tocilizumab.

*Corresponding author: M Victoria Hernández, MD, PhD, Arthritis Unit. Rheumatology Department, Hospital Clínic, Villarroel 170, stairway 11, 2nd floor, 08036 Barcelona, Spain, Tel: + (34) 932275400 ext 2236; Fax: + (34) 934515173; E-mail: mvhernan@clinic.ub.es

Received August 23, 2013; Accepted September 20, 2013; Published September 23, 2013

Citation: Hernández MV, Vidal S, Sanmarti R (2013) Analysis of the Mechanism of Action of Biological Therapies in Monotherapy in Patients with Rheumatoid Arthritis: Beyond the ADACTA Study. Adv Pharmacoepidemiol Drug Saf 2: 141. doi:10.4172/2167-1052.1000141

Copyright: @ 2013 Hernández MV, et al. This is an open-access article distributed under the terms of the Creative Commons Attribution License, which permits unrestricted use, distribution, and reproduction in any medium, provided the original author and source are credited. 


\section{Blockage of C-reactive Protein}

Tocilizumab blocks the IL-6 receptor (IL-6R). There are two forms of IL-6R: transmembrane, which is limited to a few cell types, and a soluble form (sIL-6R), that transduces the IL-6 signal to cells that do not express the transmembrane receptor. sIL-6R is often produced in an inflammatory milieu, and allows IL-6 to affect a wide variety of cells. Tocilizumab may act by binding to transmembrane IL-6R, and also to sIL-6R (trans-signaling).

IL-6 is the most critical factor that stimulates hepatocytes to produce acute phase response proteins, inducing $\mathrm{C}$-reactive protein (CRP), hepcidin and fibrinogen production, the last of which directly affects the erythrocyte sedimentation rate (ESR) [14].

CRP and ESR are good biomarkers of inflammation commonly used to assess RA disease activity, and both are components of all the scores (DAS-28, ACR response) used to analyze the RA outcomes in many clinical trials, including the ADACTA study.

CRP expression depends mainly on IL-6 signals [15]. Therefore, tocilizumab, due to its specific blocking of IL-6, quickly reduces CRP and ESR values [16]. In contrast, TNF antagonists reduce these values indirectly, as TNF stimulates CRP and fibrinogen production through IL-6.

Analysis of these effects in RA patients showed that tocilizumab rapidly reduced CRP levels after the first infusion, effect which was already observed in the second week, and remained subsequently, maintaining lower CRP levels (below the upper normal limit (UNL)), over time [17]. Although TNF antagonists also reduce CRP values, they often do not reach values below UNL as shown in studies with infliximab [18] or golimumab [19], and may contribute to worse RA scores, compared with tocilizumab.

However, the ADACTA study also calculated the CDAI score in the pos-hoc analysis and also found better results for tocilizumab than for adalimumab. As the CDAI score does not include CRP or ESR, other mechanisms must be sought to explain these results.

\section{IL-6 and the Central Nervous System}

In addition to its effects on the synthesis of hepatic inflammatory proteins, IL-6 plays an important role in the hypothalamic-pituitary axis. When a local or systemic inflammatory/immune process occurs, proinflammatory cytokines, such as IL-1 and IL-6, are released and cross the blood-brain barrier, reaching the Central Nervous System (CNS) and activating the hypothalamic-pituitary axis [20]. This activation starts when the cytokines induce nerve cells to produce and release corticotrophin releasing factor (CRF) in the hypothalamus. CRF is then transported to the anterior pituitary gland, where it stimulates a protein that serves as a basis for the adrenocorticotropin hormone, which stimulates the adrenal gland cells to produce and release cortisol. The effects of this activation are mood alteration, sleep and febrile response stimulation, and appetite and libido suppression, among others, which are frequent in patients with active RA. Moreover, IL-6 production presents, like cortisol, a circadian rhythm, with peak levels around 8:00 AM, which correlates with the morning stiffness that frequently affects RA patients with severe inflammation. In contrast, TNF does not present such a strong effect [21].

Analysis showed a significant reduction in morning stiffness and a reduction in pain and fatigue after tocilizumab infusion [22]. These parameters are closely related to the effects of IL- 6 on the CNS. Moreover, in the ADACTA study, tocilizumab was also superior to adalimumab in the SF-36 test, which was significant for the mental component [13].

Depression is a common symptom in RA patients. It may be due, in part, to alterations in the hypothalamic-pituitary axis. In addition, a relationship has been found between depression and CRP levels, with higher levels of CRP correlating with severe depression [23]. The rapid reduction in CRP values produced by tocilizumab may also have an indirect effect on depression. Improvements in depression may contribute to a better 'patient global assessment' score, a components of all the scales analyzed.

Analysis of the effect of monthly infusions of tocilizumab on fatigue, using the FACIT scale, showed the improvement after the first infusion [22] is maintained over time but also shows increasing improvement [8]. Fatigue is frequent in RA patients and, apart from the CNS component, often reflects underlying anemia, a common sign of inflammatory conditions.

\section{IL-6 and Anemia and Cardiovascular Risk}

IL-6 induces anemia in RA patients in two main ways. Firstly, by blocking iron absorption in the bowel. Secondly, by increasing levels of a protein, hepcidin, which inhibits the release of recycled iron from macrophages and absorbed iron from duodenum by binding to ferroportin and triggering lysosomal degradation of iron. Consequently, the reduction in iron release from enterocytes and macrophages leads to restriction of the iron supply for hemoglobin synthesis and, thus, to anemia [24].

By blocking the IL-6 receptor, tocilizumab avoids these two pathways, reversing the anemia. An increase of around one point in hemoglobin levels was observed in RA patients after the first infusion of tocilizumab [25], and an increase of two points at week 24. TNF antagonists also significantly increase hemoglobin levels, although the improvement ranges from 0.4 to a maximum of 0.6 points at 6 months with infliximab [26], adalimumab [3,27], and golimumab [28] The greater improvement in hemoglobin levels with tocilizumab may have effects on the reduction in fatigue and other parameters related to anemia.

Anemia rates have been correlated with higher levels of natriuretic peptide [29], which may lead to subclinical ventricular dysfunction, with anemia being an independent predictor of heart failure. Levels of anemia in patients with advanced heart failure have been associated with greater impairment in functional cardiac capacity and a significant increase in the mortality risk [30]. Therefore, improving anemia is important in RA patients to avoid this cardiovascular risk.

Currently, TNF antagonists are contraindicated in patients with advanced heart failure, based on the results of two clinical trials [31,32]. Tocilizumab has not been associated with worsening of heart failure and is not contraindicated in these patients.

Thus, tocilizumab, as a result of the improvement of anemia through increased iron release and reduced hepcidin levels, may improve cardiovascular risk in these patients and, consequently, their prognosis.

In addition to heart failure, coronary ischemia also frequently affects RA patients, increasing the risk of mortality [33]. Coronary disease in these patients is mediated by accelerated atherosclerosis due to the high levels of inflammation in RA patients [34,35]. Higher levels of CRP have been associated with an increased risk of atherosclerosis [36] and with a higher risk of myocardial infarction [37]. Moreover, an increased risk of coronary disease has been associated with higher IL-6 
levels [38]. An increased relative risk of myocardial infarction related to IL-6 levels has been found in healthy males [39].

These data suggest a crucial role for persistent inflammation, in part through increased IL-6 levels, in the risk of heart disease and, consequently, a high risk of cardiovascular morbidity and mortality.

Both inflammation and anemia are independently and additively associated with serious adverse cardiovascular events in patients with heart disease [40] and their coexistence in RA patients increases cardiovascular risk. Thus, tocilizumab due to its direct inhibition of the effects of IL-6 and therefore, reductions in CRP levels strongly might reduce the risk of atherosclerosis.

Moreover, a recent study has shown that interleukin-6 receptor seems to have a causal role in the development of coronary heart disease [41], so its blockage might may also reduces the risk of coronary heart disease.

Currently, evidence shows no increased rates of myocardial infarction in RA patients treated with tocilizumab [42] compared with the results of epidemiologic studies in patients with RA treated with non-biologic drugs [43]. TNF antagonists have not shown a lower incidence of myocardial infarction in RA patients compared with DMARD treatment, although the risk is reduced in TNF antagonist responders compared with non-responders, probably due to the control of inflammation achieved [44]. It remains to be determined whether the reduction in coronary risk in RA patients is higher with tocilizumab than with TNF antagonists, with a clinical trial to analyze the coronary risk between tocilizumab and etanercept currently ongoing [45].

\section{Different Efficacy in Monotherapy}

Strikingly, the ADACTA study found that tocilizumab had better results than adalimumab in monotherapy. Until now, all clinical trials comparing the efficacy of TNF antagonists and methotrexate were performed using combined therapy (TNF antagonist plus methotrexate showed better results than methotrexate alone) [1-5]. However, no significant improvements have been found when TNF antagonist in monotherapy has been compared to methotrexate in monotherapy in the different trials conducted: etanercept (ERA study) [46], adalimumab (PREMIER study) [47], and golimumab (GO-BEFORE study) [48]. In contrast, tocilizumab is, until now, the only biological drug that has shown a significant increase in efficacy in monotherapy compared with methotrexate in monotherapy (AMBITION study) [25].

A key feature is that methotrexate, in combination with a TNF antagonist, dose-dependently reduces the immunogenicity of TNF antagonists [49]. Immunogenicity due to TNF antagonists has been associated with a loss of efficacy [50] and therefore the combination of methotrexate with a biological drug may show more efficacy than the biological drug in monotherapy. IL-6 is a cytokine that acts on B-cells, whereas no direct TNF effect on B cells is reported. B-cells are the main producers of antibodies, such as rheumatoid factor or anti-citrullinated peptide antibodies (ACPA), both characteristic biomarkers of RA. In addition, other antibodies, such anti-drug antibodies (anti-infliximab, anti-adalimumab), related to immunogenicity may also be produced by B-cells. IL- 6 has a dual role in B cells. First, it contributes to B cell activation and, through STAT3, regulates transcription factors responsible for B cell differentiation into plasma cells [51,52]. Serum IL-6 levels have been recently correlated with markers of B cell activation and structural progression in early RA [53]. Secondly, IL-6 increases the survival of B cells and plasma cells [54]. IL-6 upregulates $\mathrm{B}$-cell activating factor (BAFF), which supports the survival of $\mathrm{B}$ cells and plasma cells [55]. As these IL-6 mediated mechanisms are directly involved in antibody production, tocilizumab may reduce the development of anti-drug antibodies and, consequently, loss of efficacy due to immunogenicity [56]. This may explain, in part, why tocilizumab could be efficacious in monotherapy.

Therefore, the question is, what additional differences between blocking IL-6 or TNF could account for the better results of tocilizumab in monotherapy?

TNF antagonists act on neutrophil recruitment and adhesion [57] and myeloid dendritic cells, reduce the expression of activation markers [58], and act on monocyte-macrophage cells, and reduce the production of pro-inflammatory cytokines [59] and nitric oxide [60-63]. Therefore, TNF antagonists affect mainly the innate immune system. The combination with methotrexate adds cell targets to TNF antagonist therapy. Methotrexate mainly targets activation of $\mathrm{T}$ and $\mathrm{B}$ lymphocytes. It inhibits purine and pyrimidine synthesis, suppresses transmethylation reactions with accumulation of polyamines, reduces antigen-dependent T-cell proliferation, and promotes adenosine release with adenosine-mediated suppression of inflammation [64] Therefore, the addition of methotrexate to TNF antagonists affects both innate and adaptive immune cells. In contrast, tocilizumab targets include a wide spectrum of immune cells. Tocilizumab reduces the levels of circulating neutrophils, myeloid dendritic cells and monocytes $[65,66]$ and the infiltration of neutrophils into inflamed joints of animal models of RA [67]. Tocilizumab also reduces the frequency of peripheral memory B cells and B cell hyper reactivity in RA patients [68], expands an intriguing B regulatory subset [69] and skews the balance between Th17 and Tregs towards a more protective status $[70,71]$. In this balance, tocilizumab plays a dual role. First, it increases the percentages of peripheral Tregs, partially through the blocking of Foxp3 down regulation in Treg cells [72,73]. Secondly, it blocks the generation of Th17 cells that require IL-6. This subset is the main producer of IL-17, a cytokine involved in the production of other pro-inflammatory cytokines by monocytes and synoviocytes (TNF, IL-1 and IL-8). IL-17 is extensively produced in RA synovium, where it has multiple targets: it promotes osteoclast differentiation, increases the migration of neutrophils, and the maturation and activation of chondrocytes [74]. Table 1 shows the different mechanisms of action of methotrexate, adalimumab and tocilizumab on different cells involved in the pathogenesis of rheumatoid arthritis

\section{Long-term Efficacy}

A reduction in long-term compliance with TNF antagonists has been observed, mainly due to a loss of efficacy over time [75], which may be observed as early as 6 months of treatment. In contrast, the number of patients with better responses increases from week 24 to 84 with tocilizumab [42]. The number of patients who remain on treatment with tocilizumab over time are significantly higher than for infliximab or adalimumab and discontinuation due to loss of efficacy is less common with tocilizumab [76]. One reason is the development of immunogenicity in patients taking TNF antagonists. Another could be the favoring of Tregs (see above). Epigenetic changes might be another, as yet unexplored, factor. Tocilizumab could progressively amend the epigenetic modifications induced by IL- 6 that contribute to RA pathology: methylation of CpG residues on specific genes such as Foxp3 [77]; altered miRNA expression [78] or DNA methylation of genes that code for regulatory proteins (SOCS1) [79].

In conclusion, the differences in the effects of tocilizumab and TNF antagonists may be due to various factors, including direct improvement 
Citation: Hernández MV, Vidal S, Sanmarti R (2013) Analysis of the Mechanism of Action of Biological Therapies in Monotherapy in Patients with Rheumatoid Arthritis: Beyond the ADACTA Study. Adv Pharmacoepidemiol Drug Saf 2: 141. doi:10.4172/2167-1052.1000141

Page 4 of 6

\begin{tabular}{|c|c|c|c|}
\hline $\begin{array}{l}\text { Therapeutical agent } \\
\text { Type of cell }\end{array}$ & Methotrexate & Adalimumab & Tocilizumab \\
\hline Neutrophils & & $\begin{array}{l}\text { Reduces neutrophil adhesion and chemotaxis } \\
\text { [57] } \\
\text { Decreases adhesion molecule expression }\end{array}$ & $\begin{array}{l}\text { Decreases levels of circulating neutrophils } \\
\text { and the infiltration of neutrophils into inflamed } \\
\text { joints [67] }\end{array}$ \\
\hline Dendritic cells & & $\begin{array}{l}\text { Decreases the level of circulating dendritic } \\
\text { cells and reduces the expression of activation } \\
\text { markers [58] }\end{array}$ & $\begin{array}{l}\text { Reduces circulating myeloid dendritic cells } \\
\text { [65] }\end{array}$ \\
\hline Monocyte-macrophage cells & $\begin{array}{l}\text { Inhibits macrophage activation [62] } \\
\text { Decreases activating receptors for } \\
\text { IgG on monocytes [63] }\end{array}$ & $\begin{array}{l}\text { Reduces the production of pro-inflammatory } \\
\text { cytokines [59] and nitric oxide [61] }\end{array}$ & $\begin{array}{l}\text { Decreases levels of monocyte cells [65] } \\
\text { Decreases serum macrophage migration } \\
\text { inhibitory factor [66] }\end{array}$ \\
\hline T cells & $\begin{array}{l}\text { Reduces antigen-dependent T-cell } \\
\text { proliferation [64] }\end{array}$ & & $\begin{array}{l}\text { Decreases Th17 cells and increases Tregs } \\
\text { cells [70-71] }\end{array}$ \\
\hline B cells & $\begin{array}{l}\text { Decreases antibody production } \\
\text { by B cells [49] }\end{array}$ & & $\begin{array}{l}\text { Reduces the development of anti-drug } \\
\text { antibodies [56] } \\
\text { Reduces the frequency of peripheral memory } \\
\text { B cells and B cell hyperreactivity [68] } \\
\text { Induces the expansion of B regulatory cells }{ }^{69}\end{array}$ \\
\hline
\end{tabular}

Table 1: Different mechanism of action of methotrexate, adalimumab and tocilizumab.

in acute reactants factors and the benefit of effects on the CNS. The efficacy of tocilizumab in monotherapy may be due to its effects on a wide spectrum of cells. Its long-term efficacy might be due to regulation of the immune system and memory. Therefore, tocilizumab, apart from its effect as a cytokine-specific therapy, may play a role in regulating the immune system.

\section{References}

1. Maini R, St Clair EW, Breedveld F, Furst D, Kalden J, et al. (1999) Infliximab (chimeric anti-tumour necrosis factor alpha monoclonal antibody) versus placebo in rheumatoid arthritis patients receiving concomitant methotrexate: a randomised phase III trial. ATTRACT Study Group. Lancet 354: 1932-1939.

2. Weinblatt ME, Kremer JM, Bankhurst AD, Bulpitt KJ, Fleischmann RM, et al. (1999) A trial of etanercept, a recombinant tumor necrosis factor receptor:Fc fusion protein, in patients with rheumatoid arthritis receiving methotrexate. $\mathrm{N}$ Engl J Med 340: 253-259.

3. Weinblatt ME, Keystone EC, Furst DE, Moreland LW, Weisman MH, et al. (2003) Adalimumab, a fully human anti-tumor necrosis factor alpha monoclonal antibody, for the treatment of rheumatoid arthritis in patients taking concomitant methotrexate: the ARMADA trial. Arthritis Rheum 48: 35-45.

4. Keystone E, Genovese MC, Klareskog L, Hsia EC, Hall S, et al. (2010) Golimumab in patients with active rheumatoid arthritis despite methotrexate therapy: 52-week results of the GO-FORWARD study. Ann Rheum Dis 69: $1129-1135$.

5. Keystone E, Heijde Dv, Mason D Jr, Landewe R, Vollenhoven RV, et al. (2008) Certolizumab pegol plus methotrexate is significantly more effective than placebo plus methotrexate in active rheumatoid arthritis: findings of a fifty-twoweek, phase III, multicenter, randomized, double-blind, placebo-controlled, parallel-group study. Arthritis Rheum 58: 3319-3329.

6. Emery P, Fleischmann R, Filipowicz-Sosnowska A, Schechtman J, Szczepanski L, et al. (2006) The efficacy and safety of rituximab in patients with active rheumatoid arthritis despite methotrexate treatment: results of a phase IIB randomized, double-blind, placebo-controlled, dose-ranging trial. Arthritis Rheum 54: 1390-400.

7. Kremer JM, Genant HK, Moreland LW, Russell AS, Emery P, et al. (2006) Effects of abatacept in patients with methotrexate-resistant active rheumatoid arthritis: a randomized trial. Ann Intern Med 144: 865-876.

8. Smolen JS, Beaulieu A, Rubbert-Roth A, Ramos-Remus C, Rovensky J, et al. (2008) Effect of interleukin-6 receptor inhibition with tocilizumab in patients with rheumatoid arthritis (OPTION study): a double-blind, placebo-controlled, randomised trial. Lancet 371: 987-997.

9. Cohen SB, Emery P, Greenwald MW, Dougados M, Furie RA, et al. (2006) Rituximab for rheumatoid arthritis refractory to anti-tumor necrosis factor therapy: Results of a multicenter, randomized, double-blind, placebocontrolled, phase III trial evaluating primary efficacy and safety at twenty-four weeks. Arthritis Rheum 54: 2793-2806.
10. Genovese MC, Becker JC, Schiff M, Luggen M, Sherrer Y, et al. (2005) Abatacept for rheumatoid arthritis refractory to tumor necrosis factor alpha inhibition. N Engl J Med 353: 1114-1123.

11. Emery P, Keystone E, Tony HP, Cantagrel A, van Vollenhoven R, et al (2008) IL-6 receptor inhibition with tocilizumab improves treatment outcomes in patients with rheumatoid arthritis refractory to anti-tumour necrosis factor biologicals: results from a 24-week multicentre randomised placebo-controlled trial. Ann Rheum Dis 67: 1516-1523.

12. Weinblatt ME, Schiff M, Valente R, van der Heijde D, Citera G, et al. (2013) Head-to-head comparison of subcutaneous abatacept versus adalimumab for rheumatoid arthritis: findings of a phase IIlb, multinational, prospective, randomized study. Arthritis Rheum 65: 28-38.

13. Gabay C, Emery P, van Vollenhoven R, Dikranian A, Alten R, et al. (2013) Tocilizumab monotherapy versus adalimumab monotherapy for treatment of rheumatoid arthritis (ADACTA): a randomised, double-blind, controlled phase 4 trial. Lancet 381: 1541-1550.

14. Gabay C, Kushner I (1999) Acute-phase proteins and other systemic responses to inflammation. N Engl J Med 340: 448-454.

15. Nishikawa T, Hagihara K, Serada S, Isobe T, Matsumura A, et al. (2008) Transcriptional complex formation of c-Fos, STAT3, and hepatocyte NF-1 alpha is essential for cytokine-driven C-reactive protein gene expression. Immunol 180: 3492-3501.

16. Choy E (2004) Clinical experience with inhibition of interleukin-6. Rheum Dis Clin North Am 30: 405-415, viii.

17. Genovese MC, McKay JD, Nasonov EL, Mysler EF, da Silva NA, et al. (2008) Interleukin-6 receptor inhibition with tocilizumab reduces disease activity in rheumatoid arthritis with inadequate response to disease-modifying antirheumatic drugs: the tocilizumab in combination with traditional diseasemodifying antirheumatic drug therapy study. Arthritis Rheum 58: 2968-2980.

18. Ban A, Inaba M, Furumitsu Y, Okamoto K, Yukioka K, et al. (2010) Time-course of health status in patients with rheumatoid arthritis during the first year of treatment with infliximab. Biomed Pharmacother 64: 107-112.

19. Kay J, Matteson EL, Dasgupta B, Nash P, Durez P, et al. (2008) Golimumab in patients with active rheumatoid arthritis despite treatment with methotrexate: a randomized, double-blind, placebo-controlled, dose-ranging study. Arthritis Rheum 58: 964-975.

20. Papadopoulos AS, Cleare AJ (2011) Hypothalamic-pituitary-adrenal axis dysfunction in chronic fatigue syndrome. Nat Rev Endocrinol 8: 22-32.

21. Perry MG, Kirwan JR, Jessop DS, Hunt LP (2009) Overnight variations in cortisol, interleukin 6, tumour necrosis factor alpha and other cytokines in people with rheumatoid arthritis. Ann Rheum Dis 68: 63-68.

22. Burmester GR, Feist E, Kellner H, Braun J, Iking-Konert C, et al. (2011) Effectiveness and safety of the interleukin 6-receptor antagonist tocilizumab after 4 and 24 weeks in patients with active rheumatoid arthritis: the first phase IIlb real-life study (TAMARA). Ann Rheum Dis 70: 755-759. 
Citation: Hernández MV, Vidal S, Sanmarti R (2013) Analysis of the Mechanism of Action of Biological Therapies in Monotherapy in Patients with Rheumatoid Arthritis: Beyond the ADACTA Study. Adv Pharmacoepidemiol Drug Saf 2: 141. doi:10.4172/2167-1052.1000141

23. Kojima M, Kojima T, Suzuki S, Oguchi T, Oba M, et al. (2009) Depression, inflammation, and pain in patients with rheumatoid arthritis. Arthritis Rheum 61: 1018-1024.

24. Stein J, Hartmann F, Dignass AU (2010) Diagnosis and management of iron deficiency anemia in patients with IBD. Nat Rev Gastroenterol Hepatol 7: 599610

25. Jones G, Sebba A, Gu J, Lowenstein MB, Calvo A, et al. (2010) Comparison of tocilizumab monotherapy versus methotrexate monotherapy in patients with moderate to severe rheumatoid arthritis: the AMBITION study. Ann Rheum Dis 69: 88-96.

26. Doyle MK, Rahman MU, Han C, Han J, Giles J, et al. (2009) Treatment with infliximab plus methotrexate improves anemia in patients with rheumatoid arthritis independent of improvement in other clinical outcome measures-a pooled analysis from three large, multicenter, double-blind, randomized clinical trials. Semin Arthritis Rheum 39: 123-131.

27. Furst DE, Schiff MH, Fleischmann RM, Strand V, Birbara CA, et al. (2003) Adalimumab, a fully human anti tumor necrosis factor-alpha monoclonal antibody, and concomitant standard antirheumatic therapy for the treatment of rheumatoid arthritis: results of STAR (Safety Trial of Adalimumab in Rheumatoid Arthritis). J Rheumatol 30: 2563-2571.

28. Furst DE, Kay J, Wasko MC, Keystone E, Kavanaugh A, et al. (2013) The effect of golimumab on haemoglobin levels in patients with rheumatoid arthritis, psoriatic arthritis or ankylosing spondylitis. Rheumatology (Oxford) 52: 18451855.

29. Desai AS, Bibbins-Domingo K, Shlipak MG, Wu AH, Ali S, et al. (2007) Association between anaemia and $\mathrm{N}$-terminal pro-B-type natriuretic peptide (NT-proBNP): findings from the Heart and Soul Study. Eur J Heart Fail 9: 886891.

30. Horwich TB, Fonarow GC, Hamilton MA, MacLellan WR, Borenstein J (2002) Anemia is associated with worse symptoms, greater impairment in functional capacity and a significant increase in mortality in patients with advanced heart failure. J Am Coll Cardiol 39: 1780-1786.

31. Chung ES, Packer M, Lo KH, Fasanmade AA, Willerson JT, et al. (2003) Randomized, double-blind, placebo-controlled, pilot trial of infliximab, a chimeric monoclonal antibody to tumor necrosis factor-alpha, in patients with moderate-to-severe heart failure: results of the anti-TNF Therapy Against Congestive Heart Failure (ATTACH) trial. Circulation 107: 3133-3140.

32. Mann DL, McMurray JJ, Packer M, Swedberg K, Borer JS, et al. (2004) Targeted anticytokine therapy in patients with chronic heart failure: results of the Randomized Etanercept Worldwide Evaluation (RENEWAL). Circulation 109: 1594-1602.

33. Gabriel SE (2008) Cardiovascular morbidity and mortality in rheumatoid arthritis. Am J Med 121: S9-S14.

34. Libby $P$ (2002) Inflammation in atherosclerosis. Nature 420: 868-874.

35. Sattar N, McCarey DW, Capell H, Mclnnes IB (2003) Explaining how "highgrade" systemic inflammation accelerates vascular risk in rheumatoid arthritis. Circulation 108: 2957-2963.

36. Libby P, Ridker PM (2004) Inflammation and atherosclerosis: role of C-reactive protein in risk assessment. Am J Med 116 Suppl 6A: 9S-16S.

37. Sakkinen P, Abbott RD, Curb JD, Rodriguez BL, Yano K, et al. (2002) C-reactive protein and myocardial infarction. J Clin Epidemiol 55: 445-451.

38. Danesh J, Kaptoge S, Mann AG, Sarwar N, Wood A, et al. (2008) Long-term interleukin-6 levels and subsequent risk of coronary heart disease: two new prospective studies and a systematic review. PLoS Med 5: e78.

39. Bennet AM, Prince JA, Fei GZ, LyrenÃas L, Huang Y, et al. (2003) Interleukin-6 serum levels and genotypes influence the risk for myocardial infarction. Atherosclerosis 171: $359-367$

40. Steinvil A, Rogowski O, Banai S, Leshem-Rubinow E, Halkin A, et al. (2013) Anemia and inflammation have an additive value in risk stratification of patients undergoing coronary interventions. J Cardiovasc Med (Hagerstown)

41. Interleukin-6 Receptor Mendelian Randomisation Analysis (IL6R MR) Consortium, Hingorani AD, Casas JP (2012) The interleukin-6 receptor as a target for prevention of coronary heart disease: a mendelian randomisation analysis. Lancet 379: 1214-1224.

42. Genovese MC, Rubbert-Roth A, Smolen JS, Kremer J, Khraishi M, et al. (2013)
Longterm safety and efficacy of tocilizumab in patients with rheumatoid arthritis: a cumulative analysis of up to 4.6 years of exposure. J Rheumatol 40: 768-780.

43. Solomon DH, Karlson EW, Rimm EB, Cannuscio CC, Mandl LA, et al. (2003) Cardiovascular morbidity and mortality in women diagnosed with rheumatoid arthritis. Circulation 107: 1303-1307.

44. Dixon WG, Watson KD, Lunt M, Hyrich KL; British Society for Rheumatology Biologics Register Control Centre Consortium, Silman AJ, et al. (2007) Reduction in the incidence of myocardial infarction in patients with rheumatoid arthritis who respond to anti-tumor necrosis factor alpha therapy: results from the British Society for Rheumatology Biologics Register. Arthritis Rheum 56: 2905-2912.

45. A study of RoActemra/Actemra (tocilizumab) in comparison to etanercept in patients with rheumatoid arthritis and cardiovascular disease risk factors.

46. Bathon JM, Genovese MC (2003) The Early Rheumatoid Arthritis (ERA) tria comparing the efficacy and safety of etanercept and methotrexate. Clin Exp Rheumatol 21: S195-S197.

47. Breedveld FC, Weisman MH, Kavanaugh AF, Cohen SB, Pavelka K, et al. (2006) The PREMIER study: A multicenter, randomized, double-blind clinical trial of combination therapy with adalimumab plus methotrexate versus methotrexate alone or adalimumab alone in patients with early, aggressive rheumatoid arthritis who had not had previous methotrexate treatment. Arthritis Rheum 54: 26-37.

48. Emery P, Fleischmann RM, Moreland LW, Hsia EC, Strusberg I, et al. (2009) Golimumab, a human anti-tumor necrosis factor alpha monoclonal antibody, injected subcutaneously every four weeks in methotrexate-naive patients with active rheumatoid arthritis: twenty-four-week results of a phase III, multicenter randomized, double-blind, placebo-controlled study of golimumab before methotrexate as first-line therapy for early-onset rheumatoid arthritis. Arthritis Rheum 60: 2272-2283

49. Krieckaert CL, Nurmohamed MT, Wolbink GJ (2012) Methotrexate reduces immunogenicity in adalimumab treated rheumatoid arthritis patients in a dose dependent manner. Ann Rheum Dis 71: 1914-1915.

50. Bartelds GM, Krieckaert CL, Nurmohamed MT, van Schouwenburg PA, Lems WF, et al. (2011) Development of antidrug antibodies against adalimumab and association with disease activity and treatment failure during long-term followup. JAMA 305: 1460-1468.

51. Yamasaki K, Taga T, Hirata Y, Yawata H, Kawanishi Y, et al. (1988) Cloning and expression of the human interleukin-6 (BSF-2/IFN beta 2) receptor. Science 241: 825-828

52. Iwakoshi NN, Lee AH, Glimcher LH (2003) The X-box binding protein-1 transcription factor is required for plasma cell differentiation and the unfolded protein response. Immunol Rev 194: 29-38.

53. Gottenberg JE, Dayer JM, Lukas C, Ducot B, Chiocchia G, et al. (2012) Serum IL-6 and IL-21 are associated with markers of B cell activation and structural progression in early rheumatoid arthritis: results from the ESPOIR cohort. Ann Rheum Dis 71: 1243-1248.

54. Jego G, Robillard N, Puthier D, Amiot M, Accard F, et al. (1999) Reactive plasmacytoses are expansions of plasmablasts retaining the capacity to differentiate into plasma cells. Blood 94: 701-712.

55. Cancro MP, D'Cruz DP, Khamashta MA (2009) The role of B lymphocyte stimulator (BLyS) in systemic lupus erythematosus. J Clin Invest 119: 1066 1073.

56. Stubenrauch K, Wessels U, Birnboeck H, Ramirez F, Jahreis A, et al. (2010) Subset analysis of patients experiencing clinical events of a potentially immunogenic nature in the pivotal clinical trials of tocilizumab for rheumatoid arthritis: Evaluation of an antidrug antibody ELISA using clinical adverse eventdriven immunogenicity testing. Clin Ther 32: 1597-609.

57. Dominical VM, BÃ@rtolo MB, Almeida CB, Garrido VT, Miguel LI, et al. (2011) Neutrophils of rheumatoid arthritis patients on anti-TNF-ît therapy and in disease remission present reduced adhesive functions in association with decreased circulating neutrophil-attractant chemokine levels. Scand J Immuno 73: 309-318.

58. Balanescu A, Radu E, Nat R, Regalia T, Bojinca V, et al. (2005) Early and late effect of infliximab on circulating dendritic cells phenotype in rheumatoid arthritis patients. Int J Clin Pharmacol Res 25: 9-18.

59. Rossol M, Meusch U, Pierer M, Kaltenhäuser S, Häntzschel H, et al. (2007) 
Citation: Hernández MV, Vidal S, Sanmarti R (2013) Analysis of the Mechanism of Action of Biological Therapies in Monotherapy in Patients with Rheumatoid Arthritis: Beyond the ADACTA Study. Adv Pharmacoepidemiol Drug Saf 2: 141. doi:10.4172/2167-1052.1000141

Interaction between transmembrane TNF and TNFR1/2 mediates the activation of monocytes by contact with T cells. J Immunol 179: 4239-4248.

60. Gonzalez-Gay MA, Garcia-Unzueta MT, Berja A, Vazquez-Rodriguez TR, Miranda-Filloy JA, et al. (2009) Short-term effect of anti-TNF-alpha therapy on nitric oxide production in patients with severe rheumatoid arthritis. Clin Exp Rheumatol 27: 452-458.

61. Perkins DJ, St Clair EW, Misukonis MA, Weinberg JB (1998) Reduction of NOS2 overexpression in rheumatoid arthritis patients treated with anti-tumor necrosis factor alpha monoclonal antibody (cA2). Arthritis Rheum 41: 22052210.

62. Johnson WJ, DiMartino MJ, Meunier PC, Muirhead KA, Hanna N (1988) Methotrexate inhibits macrophage activation as well as vascular and cellular inflammatory events in rat adjuvant induced arthritis. J Rheumatol 15: 745-749.

63. Wijngaarden S, van Roon JA, van de Winkel JG, Bijlsma JW, Lafeber FP (2005) Down-regulation of activating Fcgamma receptors on monocytes of patients with rheumatoid arthritis upon methotrexate treatment. Rheumatology (Oxford) 44: 729-734.

64. Tian H, Cronstein BN (2007) Understanding the mechanisms of action of methotrexate: implications for the treatment of rheumatoid arthritis. Bull NYU Hosp Jt Dis 65: 168-173.

65. Richez C, Barnetche T, Khoryati L, Duffau P, Kostine M, et al. (2012) Tocilizumab treatment decreases circulating myeloid dendritic cells and monocytes, 2 components of the myeloid lineage. J Rheumatol 39: 1192-1197.

66. Kasama T, Isojima S, Umemura M, Tsukamoto H, Tokunaga T, et al. (2013) Serum macrophage migration inhibitory factor levels are correlated with response to tocilizumab therapy in patients with rheumatoid arthritis. Rheumatol Int.

67. Uchiyama Y, Yorozu K, Hashizume M, Moriya Y, Mihara M (2008) Tocilizumab, a humanized anti-interleukin- 6 receptor antibody, ameliorates joint swelling in established monkey collagen-induced arthritis. Biol Pharm Bull 31: 1159-1163.

68. Roll P, Muhammad K, Schumann M, Kleinert S, Einsele H, et al. (2011) In vivo effects of the anti-interleukin- 6 receptor inhibitor tocilizumab on the $B$ cell compartment. Arthritis Rheum 63: 1255-1264.
69. Snir A, Kessel A, Haj T, Rosner I, Slobodin G, et al. (2011) Anti-IL-6 receptor antibody (tocilizumab): a B cell targeting therapy. Clin Exp Rheumatol 29: 697700 .

70. Pesce B, Soto L, Sabugo F, Wurmann P, Cuchacovich M, et al. (2013) Effect of interleukin- 6 receptor blockade on the balance between regulatory $T$ cells and $T$ helper type 17 cells in rheumatoid arthritis patients. Clin Exp Immunol 171: $237-242$

71. Samson M, Audia S, Janikashvili N, Ciudad M, Trad M, et al. (2012) Brief report: inhibition of interleukin-6 function corrects Th17/Treg cell imbalance in patients with rheumatoid arthritis. Arthritis Rheum 64: 2499-2503.

72. Ziegler SF (2008) Regulatory T cells and inflammation: better late than never Immunity 29: 5-7.

73. Ziegler SF, Buckner JH (2009) FOXP3 and the regulation of Treg/Th17 differentiation. Microbes Infect 11: 594-598.

74. Miossec $P$ (2008) Th 17 Cells and Arthritis. The true story of how IL-17 became a focus for RA research. The Rheumatologist, July.

75. Gomez-Reino JJ, Carmona L; BIOBADASER Group (2006) Switching TNF antagonists in patients with chronic arthritis: an observational study of 488 patients over a four-year period. Arthritis Res Ther 8: R29.

76. Hishitani Y, Ogata A, Shima Y, Hirano T, Ebina K, et al. (2013) Retention of tocilizumab and anti-tumour necrosis factor drugs in the treatment of rheumatoid arthritis. Scand J Rheumatol 42: 253-259.

77. Notley CA, Ehrenstein MR (2010) The yin and yang of regulatory T cells and inflammation in RA. Nat Rev Rheumatol 6: 572-577.

78. Schwabe RF, Wang TC (2011) Targeting liver cancer: first steps toward a miRacle? Cancer Cell 20: 698-699.

79. Shortt J, Hsu AK, Johnstone RW (2013) Thalidomide-analogue biology: immunological, molecular and epigenetic targets in cancer therapy. Oncogene 32: 4191-4202. 